\title{
The Obstacles and Strategy of Project Based Learning Implementation in Elementary School
}

\author{
Nyai Cintang ${ }^{1 *}$, Dewi Liesnoor Setyowati ${ }^{2}$, Sri Sularti Dewanti Handayani ${ }^{3}$ \\ ${ }^{1}$ Study Program of Primary Education, Departement of Education, Universitas PGRI Semarang, Indonesia \\ ${ }^{2}$ Departement of Social Science, Universitas Negeri Semarang, Indonesia \\ ${ }^{3}$ Departement of Early Childhood Educaton, Universitas Negeri Semarang, Indonesia
}

\begin{tabular}{l} 
Article Info \\
\hline Article history: \\
Received Oct 19, 2017 \\
Revised Dec 22, 2017 \\
Accepted Jan 19, 2018 \\
\hline
\end{tabular}

\section{Keywords:}

Curriculum 2013

Obstacle

Project based learning

Strategy

\begin{abstract}
This study aims to: 1) examine the challenges teachers encounter in implementing project-based learning in 2013 curriculum, 2) to examine teachers' strategies in integrating project-based learning in 2013 curriculum. This research finds several obstacles faced by teachers and strategies that can be done in the implementation of project-based learning, they are: 1) the obstacle in terms of students' capability can be overcome by familiarizing them to complete projects; 2) the obstacle in terms of indiscipline can be solved by optimizing the teacher's role as supervisor; 3 ) the time constraint is overcome by some alternative ways; 4) the obstacle in terms of equipment availability is addressed by modifying projects; 5) the obstacle in terms of student's inequality is overcome by forming propori sembang group; 6) the cost issues are resolved by using classroom cash or selecting projects suitable for the available resources. Another positive finding is that teachers should have the confidence and commitment in implementing project-based learning. Based on these results, it can be concluded that most teachers and even experienced teachers will experience difficulties and challenges when trying to implement project-based learning. However, experienced teachers have strategies to overcome obstacles, thus project-based learning can still be implemented.
\end{abstract}

Copyright $\odot 2018$ Institute of Advanced Engineering and Science. All rights reserved.

\section{Corresponding Author:}

Nyai Cintang,

Departement of Primary Education,

Universitas PGRI Semarang, Indonesia

Email: nyaicintang@gmail.com; nyaicintang@upgris.ac.id

\section{INTRODUCTION}

Classroom learning process that implements project-based learning will direct the students' active role in learning. In addition to observing the stage of student thinking development, learning activities should also pay attention to the diversity of learning styles and characteristics of students. Motivating and engaging students in active learning is challenging even for the most experienced teachers [1]. Due to students' different learning styles, cultural and ethnic backgrounds, either a "onesize fits-all" approach or the "cookiecutter" approach" can be recommended [1].

Heterogeneous classes show a variety of students' style of learning. It is important to provide learning opportunities in various ways, individually, collectively, with teacher direction, through direct experience, or through examples and practices. Project-based learning provides an opportunity for students to learn according to their individual learning styles. In project-based learning, students are allowed to explore their skills and capabilities in accordance with their respective plans. Learning-based project implementation provides many benefits for students. Students will learn through the concept of learning by doing.

The transformation of "learning by memorizing" to "learning by doing" affects the students comprehension of learning materials. According to Edgar Dale's cone of learning cited by Anderson, learners 
will easily receive information conveyed by teachers through activities that involve the students, doing and saying, not merely hearing and seeing [2]. This is reinforced by the opinion that learning will be more meaningful if students experience what they learn, not just know it [3]. Therefore, project-based learning is applied to the elementary schools of the 2013 curriculum pilot project.

To the end of the academic year 2016/2017, the implementation of project-based learning in pilot schools ideally would has been running for 4 (four) years. In Banyumas Regency, there are 11 elementary schools of the 2013 curriculum pilot project. This research was conducted on teachers of 4th and 5th grades, in sum there were 22 teachers.

As the results of the preliminary study, it was found that only 7 teachers implementing project based learning, while 15 teachers did not implemented it for several reasons. The data were obtained based on the conclusions of general sense results through in-depth interviews.

First, the teacher was not aware of the class project provided on sub-theme 4 because they were more likely to follow the student book rather than the teacher book. Projects were not listed class projects in the student book, so the teachers were not aware of any sub-theme 4. Second, teachers had the wrong concept related to the class project intended in this research. The teacher believed that the project had been conducted, however, it turned out that the intended project was a competence task found in the lesson instead of the project class on sub-theme 4. Third, the teachers had difficulties and were not be able to implement project-based learning because of those difficulties. Fourth, 5th grade teachers of private elementary schools had particular reasons not to implement project-based learning. In the beginning of grade 5, the curriculum of the private elementary school was modified for the preparation of the national examination. The learning material for 5th grade was a slice of 5th and 6th grades learning material. Thematic learning method was still employed in the 5th grade, however, specific teachers was assigned to teach the subjects tested in the national exam. The materials studied were more on the preview of national exam, the project activity on sub-theme 4 was not implemented yet.
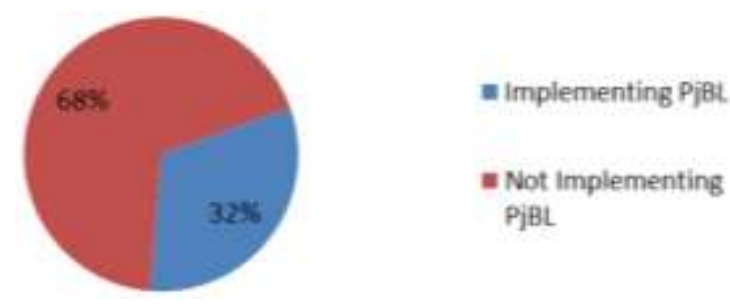

Figure 1. The percentage of teachers implementing $\mathrm{PjBL}$

Figure 1 shows the number of teachers who have the capability to implement project-based learning. Therefore, this research will examine the obstacles and strategies in the implementation of project-based learning. The research is based on the experience of teachers who have implemented project-based learning for almost four years of 2013 curriculum implementation. Informant teachers who have implemented projectbased learning are still experiencing difficulties, but each teacher has their strategies to continue the implementation of project based learning. The results study about perception of primary school teacher toward the implementation of project based learning show that there are some problems of various teacher's perception on project based learning. The diversity of teachers' perceptions will influence the implementation of project based learning in each pilot project school [4].

Teachers with difficulties and challenges in integrating project-based learning on thematic learning tend to avoid applying and implementing it in the classroom. In fact, project-based learning is ideally conducted in accordance with the mandate of 2013 curriculum shift. Therefore, this research will also examine the strategies that can be employed to find out how the teachers remain to be able to implement project-based learning on thematic learning, where some other teachers have difficulty implementing projectbased learning.

The results of this research can provide more accurate information for teachers in other schools to integrate project-based learning in the 2013 curriculum, so that the learning objectives are in accordance with the target implementation of 2013 curriculum, equip the ability of the 21 st century, and prepare competitive human resources to face the Asean Economic Community (AEC). The objectives of the research are 1) to examine the challenges teachers encounter in implementing project-based learning in 2013 curriculum, 2) to examine teacher's strategy in integrating project-based learning in 2013 curriculum. 


\section{RESEARCH METHOD}

This research was conducted as a qualitative research with case study approach. This research underwent in in depth exploration toward the challenges teachers encountered in implementing project-based learning and identified the teacher's strategies in integrating project-based learning on thematic learning in 2013 curriculum for 4 th and 5 th grades.

The pilot project elementary school sample was selected using a strict purposive sampling technique. The research subject was teachers who were experienced in implementing project based learning. The selected research sample consisted of four 4th grade teachers and three 5th grade teachers, totally there were 7 informant teachers.

The instruments of data collection instruments in this research were (a) interview guides, (b) observation sheets, and (c) documentation study sheets. The results of data collection were then tested its validity to check the level of data confidence. The validity test was done through triangulation technique of sources and methods. The method of analysis used in this research was Miles and Huberman's interactive analysis.

\section{RESULTS AND ANALYSIS}

\subsection{The Obstacles of Project-Based Learning Implementation \\ 3.1.1. Teacher's Difficulties}

Teachers who have been able to implement project-based learning are still experiencing difficulties. Although the teachers choose a project with various considerations, they still face difficulties when implementing project-based learning. The implementation of project-based learning requires preparation and planning [4].

First, the teachers face difficulty of mastering the project. Some teacher finds it difficult to start a project, especially when they have not independently implemented the project. Therefore, the teachers should have learned the theory from various sources to equip them with capability. Since the implementation of project based learning has not been discussed in the training of the 2013 curriculum, the teachers find it difficult to master the project.

The second difficulty is in terms of time management. The teachers feel that in order to implement project-based learning, they must have a good time management skill. Teachers who have been able to implement project-based learning should have the capability to manage time, so that all materials can be completed.

The third one is technical difficulties of project implementation. In addition to experiencing time constraints, teachers also experience technical obstacles as students are indiscipline in following the work procedures that have been established. Student discipline in completing projects becomes a technical obstacle, so implementation of project based learning is hampered. This indiscipline factor in completing projects becomes a technical obstacle that leads to the difficult implementation of project based learning.

Fourth, the project result is not maximal, particularly on the type of project that produces real products. Limited time allocation and lack of student skills drive the students to hastily complete the project so that the result is not maximal. Therefore, teachers are concerned more with the process than the outcome.

The fifth is inequality of students' capabilities. Differences in student's characteristics brings about the inequality of students' capabilities. When group formation is not appropriate, there will be a project completion gap between groups.

Every teacher has their own difficulties in the implementation of project-based learning. Based on the explanation above, five difficulties are found, namely: 1) the difficulty in mastering the project; 2) the difficulty in time management; 3) technical difficulties of project implementation; 4) the difficulty as the project result is not maximal; and 5) the inequality of students' capabilities. Even experienced teachers are still experiencing these difficulties in their duties. The result of this research is in harmony with Habók \& Nagy who states that we maintain that projects need a considerable amount of preparation and planning, but the benefits are indisputable [5]. The analysis of Gillies and Boyle supports the findings of this research since their analysis suggests that teachers gained valuable experience using project-based learning, but they also encountered a number of difficulties [6].

\subsubsection{Impeding Factors}

Implementing project-based learning is a very challenging job for every teacher as it requires changes in all major aspects such as curriculum, learning strategies, and the roles of both teachers and students in the learning process [7]-[9]. There are several impeding factors in the implementation of project based learning. Each teacher has their own opinion about this. After data analysis and interpretation, it obtained five impeding factors in the implementation of project based learning. 
First, it is the time factor. Time limitation is a major factor causing teachers not to implement project-based learning. All teachers agree that it is the key problem leads to the failure of project-based learning implementation. Moreover, there so many materials and lessons to be learn by students.

The second factor is the teacher's capability. Teachers function as facilitators who accompany, and guide students in project completion. Therefore, the teacher should master the project being done by the students. This lack of factor will obstruct the project execution. Teacher is lack of the capability due to the teacher has never attended any special training related to the implementation of project-based learning. In addition to the teacher's capability of mastering the project, the capability of implementing project-based learning is also required. If the teacher does not have a good time management skill, then the teacher will face a difficulty in managing it. Rogers et al. explained that the absence of teacher's capability can hinder the implementation of project-based learning [9]. Teacher's ability to communicate and assess the students' projects, ensuring that the students gain the knowledge, and facilitating the process of acquiring the knowledge are crucial. [9]

The third factor is student's skills. Students act as executors who will prepare and execute the project. Therefore, students need the skills that will be used in completing the project, including: discipline, teamwork, and activeness. In contrast, student's indiscipline will be a factor impeding the project completion. This research findings support the research result of Rogers et al. that using project based learning approach involved the challenge of helping students to adjust to a new style of learning [9].

The fourth factor is the project type. In teacher book, there are some projects that considered difficult to be implemented by teachers, such as the project that requires traveling activity or needed to be conducted outside the school. Every teacher has different opinions on difficult project. The teacher's perception of difficult projects is closely related to the teacher's ability to master the projects. Those hardexecuted projects are due to the difficulty of providing tools and materials.

The fifth is the factor of cost. The implementation of project-based learning is highly costed in order to purchase the necessary tools and materials. The absence of financial support will hinder the implementation of project based learning. Each teacher has their own difficulties.

Based on the explanation above, five impeding factors are found, namely: 1) the factor of time availability; 2) the factor of teacher's capability; 3) the factor of student's capability; 4) the factor of project type; and 5) the factor of cost.

\subsubsection{Student's Capability in Executing the Project}

There is the assumption that project-based learning will burden our elementary school students. The arising assumption is that project-based learning is not suitable to be applied in the elementary school level. Elementary school students are considered incapable of creating and executing projects.

The interview result shows that the assumption is wrong. All informant teachers agree that all students are capable of carrying out projects. However, students' capabilities are widely varied. This is a common condition in a heterogeneous class. In addition, teachers argue that students are able to carry out projects as long as there is still guidance from the teacher. The assumption that elementary school students are incapable of carrying out projects is also disputed by Hallermann, S., Larmer, J., \& Mergendoller. They consider that there is misconception of PBL, that young children are not ready for rich content [10]. There is not enough instructional time for science and studies focused projects [10]. We need to teach basic literacy and math skill first [10].

Students will be able to execute the project because the teacher has already considered the student's capabilities before establishing the designed project. These findings are in line with the opinion of Hallermann, S., Larmer, J., \& Mergendoller that in fact, teacher of all students from preschool through graduate school have used PBL effectively [10]. You just have to make adaptation based on your students need.

\subsubsection{The Obstacles That Can Be Solved By the Teacher}

There are some challenges that can be overcome in order to continuously implement project-based learning. These ways of resolving the challenges and obstacles can be applied by other teachers. First, projects that is difficult to execute can be done by modifying the project. The necessary tools and materials should be tailored to the availability of natural resources in students' environment. Second, financial problem for the project cost can be overcome by using class cash money. Third, the obstacle in terms of limited time can be solved by combining two lessons into one if you want to implement the project at the end of the theme. Other way, you can input the project during learning process because project must not only be implemented at the end of a theme. Fourth, the inequality of students' capabilities can be addressed by dividing the heterogeneous groups. The division of the group should suit the type of project to be implemented. To be sure, the teacher is better in understanding the capability of each student. 
Cintang, Setyowati \& Handayani found that all of the teachers who have implemented project-based learning agree that this method is important to apply in the classroom [4]. This is in accordance with the opinion of Yusoff, Mae, Abdullah, et al Project based learning is important in the learning process [1]. Each teacher presented different reasons about the advantages the students get through the implementation of project based learning in the classroom, such as makes the students understand more and remember what has been learned for a longer period; (b) students can develop their artistic talents; (c) develop students' skills, both hard skills and soft skills; (d) can change the teacher-centered approach to the student-centered approach; (e) students can receive the right to be a mini designer [4].

\subsection{The Strategy of Implementing Project-Based Learning 3.2.1. Implementation Strategy}

This research examines the strategies that teachers have in implementing project-based learning on thematic learning. The results shows that teachers have various strategies to continuously implementing project-based learning on thematic learning.

The first strategy lies in the teacher's belief and commitment. Teacher's belief to implement projectbased learning raises their awareness, intention and responsibility. Based on the result of the interview, teacher's belief greatly affects the learning process. A lot of research results support the findings of this research.

Hawanti suggests that many studies have been conducted to investigate teachers' knowledge and beliefs and they confirm that knowledge and beliefs are an influential factor in teachers' decision making in the classroom [11]. This is the basis for teachers to continue implementing project-based learning. The research result by Etmer et. al. agree that there is relationship between teacher's beliefs with learning practices. Ertmer, Ottenbreit-Leftwich, Sadik, Sendurur, \& Sendurur [12] states, "We examined that the beliefs and practices have a strong aligmnment. . . as well as their perceptions of the barriers impacting their practices. . . practices that closely aligned with their beliefs."

Besides the teacher's belief, the teacher's commitment to work on their duties becomes another influencing factor. Teacher's commitment is very important for successful implementation of project-based learning. Committed teachers would pursue various attempt in order to facilitate their students in the skill development. Good teachers should acknowledge the importance of project-based learning for students. Their strong commitment is realized with the motivation of trying to implement project-based learning, and considering all of the obstacles. Teachers who are committed to having awareness to be responsible for developing their students' skills through project based learning. The teacher's commitment has an important role in the inclusion of students' capabilities. Tuğrul Mart conveys that committed teachers recognize and endeavor to fulfill their responsibilities to their students [13]. Teachers, who are engaged in their profession and committed to students and their learning, play a crucial role in development of students [13].

Based on the description above, it can be concluded that the belief and commitment of committed teachers is the main strategy in implementing project-based learning. To implement project-based learning, teachers must have the belief about the benefits of project-based learning for the students. The strong belief in the importance of project-based learning will encourage the teachers to have commitment in carrying out their duties and responsibilities to their students' learning. Therefore, researchers put the teacher's belief and commitment as the first strategy. A research by Ros, J.A \& Gray supports the findings of this research, that: The substantive contribution of our study is that it has demonstrated that teacher's beliefs about their capacity and professional commitment mediate the impact of principals on student achievement [14]. Committed teachers recognize and endeavor to fulfill their responsibilities to their students. Rogers, et.al agree that the combination of teacher beliefs and experience gives teachers the strength to guide and strive to continue implementing project-based learning [9].

The second strategy is combining the project with learning or combining two interconnected learning into one. If the project is saved for the end of the theme and the time is limited, the teacher can combine the two related learning. Alternatively, the teacher can include the project in the learning activities. Projects do not always have to be put at the end of the theme.

The third strategy is creating a semester program by calculating the effective weeks details. After knowing the number of the effective weeks, the teacher can estimate the time allocation that can be used to implement the project. When the teacher already knows the details of the effective weeks, the teacher may decide to use the second strategy.

The fourth strategy is to modify the project listed in the teacher book. Teachers can develop and tailored projects to the student environment. Teachers can replace tools and materials that are difficult to find or change the context of the project implementation. If the work procedures in the teacher book makes it difficult for students, the teacher may arrange a work procedures tailored to the capabilities of both teachers and students. At the most important thing in project-based learning is the process. The project-based learning 
process can provide students with the skills required. Fifth, the last strategy is to choose an easy project and provide appropriate time to project needs. This is the easiest strategy to initiate a project implementation.

Based on the description, there are five strategies by the teachers in implementing project-based learning, which can already be overcome by the teacher. They are: 1) teacher's belief and commitment; 2) merging relevant projects or learning; 3) creating a semester program by calculating the effective weeks details; 4) modifying the project listed in the teacher book; 5) choosing a convenient projects and providing the time appropriate to project needs.

These positive findings indicate that teachers who seek to implement project-based learning will find their own ways and strategies through many experiences they have encountered. Most experienced teachers have found difficulties in managing project-based learning, but they keep trying to invent some fresh teaching methods. The results of this research are supported by Hallermann, S., Larmer, J., \& Mergendoller that for teacher who used to direct instruction, it may be challenging at first to manage students working in teams and handle the open-endedness of PBL, but with more experience it gets easier [10].

\subsubsection{Succeeding Factors}

The success of a project is influenced by factors such as the learner's capability, the availability of financial support, the type of project, the student's capability to accept the teacher's explanation, and other factors. By interview and observation, it is found 3 (three) main factors of project success.

The first factors are cooperation and cohesiveness. The success of project-based learning implementation is strongly influenced by the good cooperation between students with teachers, or the cooperation among students. In addition, group cohesiveness also greatly affects the project success. The findings of this research are consistent with the opinion of Hallermann, S., Larmer, J., \& Mergendoller that collaboration is an important instructional strategy, especially used in conjunction with project-based learning, and is an essential learning outcome for the twenty-first century [10].

The second factor is student's activeness. The success of project based learning implementation is also strongly influenced by students' activeness in learning. Next, the role of teacher as supervisor when conducting monitoring is one of the succeeding factor of project-based learning implementation. Teachers should consider their intensity of monitoring student progress.

Based on the explanation above, three factors that influence the successful implementation of project based learning are found. They are: 1) cooperation and cohesiveness of students and teachers; 2) student's activeness; and 3) the role of teacher as supervisor. The findings of this research can be a consideration for teachers in implementing project-based learning. This is reinforced with the opinion of Krajcik et al. that successful implementation of project-based learning requires (1) extended PD for teachers, (2) sustained classroom support (e.g. with technology and curriculum development), and (3) collaboration and commitment from school personnel [8]. Rogers, Cross, Gresalfi, Nare A, \& Buck support Krajcik's opinion that in addition to those three criteria, teacher's orientation and past professional experience should also be considered as this may ultimately affects the teacher's commitment to project-based learning [9]. In contrast to the succeeding criteria of project based proposed by Habók \& Nagy, they argue that student activity and good atmosphere are the key characteristics of a successful project [5].

\subsubsection{Solutions to Overcome the Existed Obstacles}

The obstacles faced by teachers can be overcome complying with the difficulties or challenges that happen. The research of Cintang, Setyowati \& Handayani found about teacher perception that project based learning is important but not all of the lesson items need to conduct a project [4]. Based on that research findings, it is important to be known by the teacher prior to determining the strategies that will be applied when planning a design project-based learning. The following will show the types of obstacle and how to overcome them. Some alternative ways to overcome the obstacles in the implementation of project-based learning are based on the experience of teachers who have implemented it before.

The first problem is about student's capability. This can be solved by continuing to try to implement the project. Project-based learning can familiarize the students with skills and capabilities. It can be trained with habits. The teacher should let the students do the project according to their capabilities. Teachers can provide the students opportunities to complete their task in their own way. The role of the teacher is to guide, not to teach. This statement is supported by Education Technology Division that teachers should allow students to go in new direction and guide them when they appear to be going in the direction that has no connection to the project [1]. At the end of every project, the teacher can evaluate it and provide feedback to the students. This is done to provide information to students about their strength and the shortcomings they have to address. Their shortcoming and weakness can be improved on the next project.

The second problem is student discipline. Teacher should act as a supervisor to overcome this issue. As a supervisor, the task of the teacher is to oversee the progress and readiness of the students in completing 
the project. Teachers should conduct monitoring to observe the difficulties faced by students in the process. Cintang, Setyowati \& Handayani argue that the teacher plays a role in supervising, monitoring and reminding. The teacher acts in controlling the execution of project to match the time specified [4]. The teachers monitor the students' readiness, and supervise whether anyone is having problems finishing the project. Hallermann, Larmer, \& Mergendoller agree that teacher plays a vital role in farming the experience through careful planning, facilitating inquiry process, assessing learning, and managing logistics [10].

If the project is to be performed in the school, the teacher should ensure that the students are ready for it before starting the project. Give students the opportunity to take responsibility and have a personal awareness of the project. When conducting a project, do not be too strict nor force the students. The teacher plays an important role as a supervisor in charge of monitoring student progress.

This opinion is in harmony with Education Technology Division [1] that teachers should be flexible, but help students realize that the time will come when they need to finalize their thoughts, findings, and evaluations. Help students to stay on course but do not accidentally set limitation.

The third problem is time constraints. This problem can be overcome in several ways, such as: 1) by combining two related material into one learning if the project is to be implemented at the end of the theme; 2) by including project activity on the learning if the material is too large to combine; 3) by creating effective weekly breakdowns to determine the time allotted for one semester; 4) by shortening the project implementation time; and 5) by finding the right time to carry out the project.

The fourth problem is the difficulties to find the needed tools and materials. This problem can be solved by modifying the project. Teachers can develop projects according to the situation. Teachers can modify tools and materials as well as the procedures to do the project.

The fifth problem is the inequality of students' capabilities. This problem can be solved by forming a heterogeneous group tailored to the type of the project to be implemented. As a teacher, understanding the students' capabilities is required. Before forming a group, it is better for the teacher to identify what capabilities are needed to complete the project. Next, the teacher can map the group members according to the students' capabilities. The teacher should divide the students evenly, based on the level of the student's capabilities. Strive for the balanced portion of student's capabilities in each group.

The sixth is cost issue. This problem can be solved by using classroom cash or school funds. Project materials can be replaced in accordance with the available resources. Table 1 presents the obstacles in the implementation of project-based learning and the strategies to address it.

Table 1. The Obstacles and the Strategies in the Implementation of Project-Based Learning

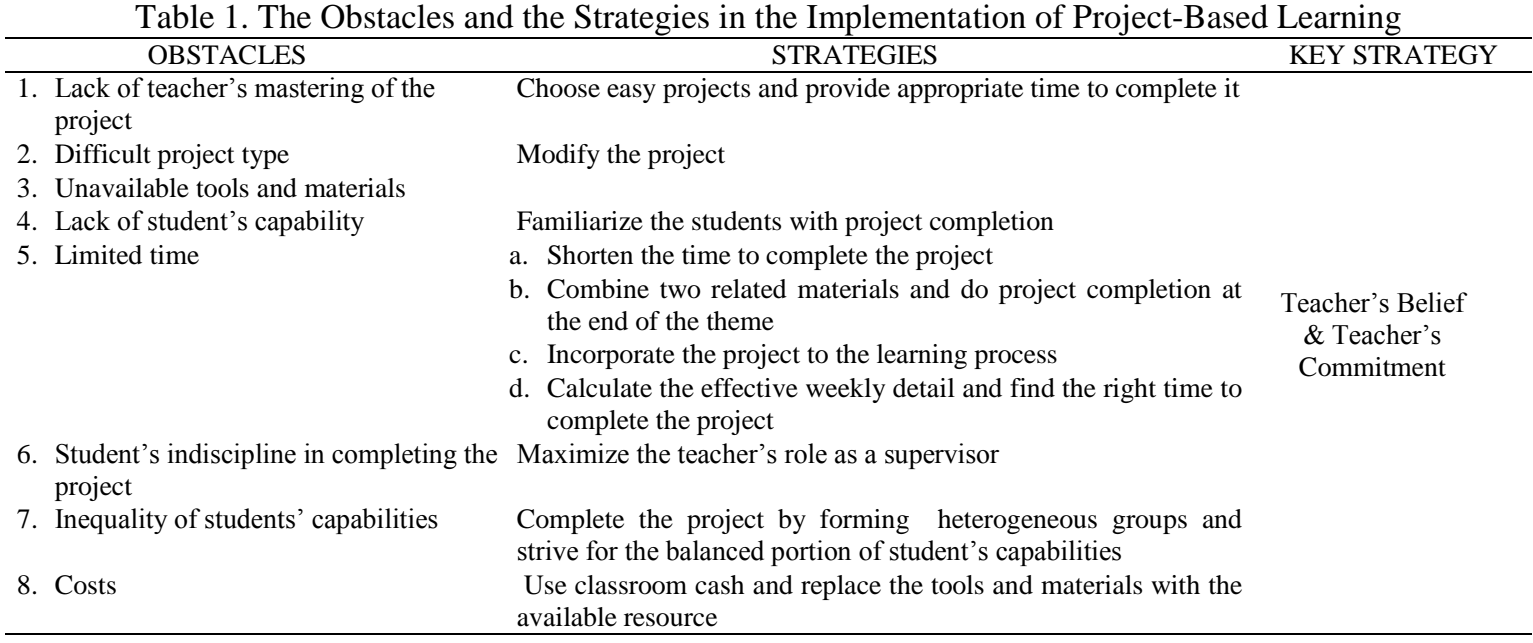

Abdullah divides the implementation of project-based learning into procedural planning and process planning [15]. Project-Based Learning should be initiated from adequate learning planning, therefore procedural planning is required before implementing the project. In learning poses, the teacher should also consider all possibilities that occur when implementing project-based learning. The following Table 8.1 will formulate the obstacles and the strategies mapped into the strategies on procedural planning and the strategies on the project-based learning process. 


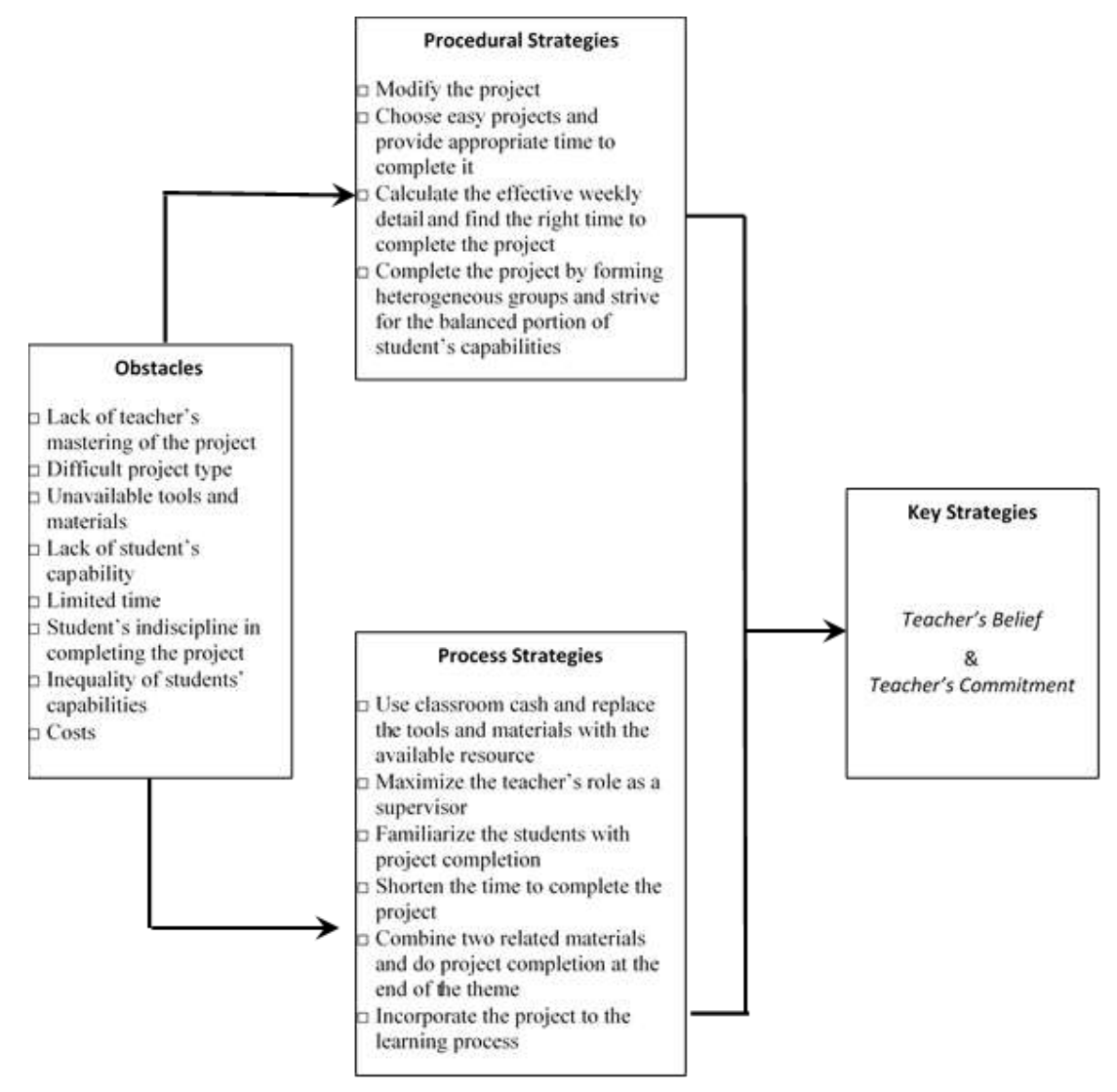

Figure1. The Scheme of the Obstacles and the Strategies in the Implementation of Project-Based Learning

\section{CONCLUSION}

Most teachers and even experienced teachers will experience difficulties and challenges when trying to implement project-based learning. The result of the research concludes that the obstacles are caused by the fact that the teacher has never attended any specific training on the implementation of project-based learning. Experienced teachers have a strategy of implementing project based learning on thematic learning. Teachers who do not have a strategy decide not to implement project-based learning. The strategy in the implementation of project-based learning consists of procedural strategies and process strategies. Procedural strategies applied when designing project-based learning activities, while the process strategies applied at the time of project-based learning implementation process on thematic learning. There are main strategies that teachers must have in order to implement project-based learning on thematic learning, namely teacher's belief and teacher's commitment.

\section{REFERENCES}

[1] D.Yusoff, C.F. Mae, N.A Abdullah, J. Johari, F. Arifin, N.M.Yusof, et.al. "Project Based Learning Handbook Educating the Milennial Learner". Educational Technology Division. Malaysia: Kuala Lumpur Communications and Training Sector Smart Educational Development Ministry of Education, 2006, pp 1-47

[2] E. Dale. Audio-Visual Methods in Teaching, revised edition. New York : A Holt-Dryden, 1954, pp.108

[3] A. Majid. 2014. Pembelajaran Tematik Terpadu. Bandung: PT. Remaja Rosdakarya.

[4] N. Cintang, L. Setyowati, Handayani S. Sri Sularti. "Perception of Primary School Teacher towards the Implementation of Project Based Learning," Journal of Primary Education, Vol 2, 2017, pp. 81-93

[5] A. Habók and J. Nagy, "In-service teachers' perceptions of project-based learning," International Journal of A SpringerPlus, vol. 5, pp. 1-14, 2016.

[6] R.M. Gillies and M. Boyle, Teachers' reflections on cooperative learning: issues of implementation. Teaching Education, 2010, pp. 933-940

[7] P. Blumenfeld, C. Soloway, R. Marx, J Krajcik, M. Guzdial and A. Palinscar, "Motivating project-based learning: Sustaining the doing, supporting the learning." International Journal Educational Psychologist, 1991, pp. 369-398

[8] J.S. Krajcik, P.C. Blumenfeld, R. W. Marx, and E. Soloway, "A collaborative model for helping middle grade science teachers learn project-based instruction," The Elementary School Journal, Vol. 94, pp. 483-497, 1994. 
[9] M.A. Rogers, D. Cross, M. Gresalfi, A.E. Nare and G. Buck, "First Year Implementation of a Project-Based Learning Approach: the Need for Addressing Teachers'Orientations in the Era of Reform," International Journal of Science and Mathematic Education. Vol 9, 2011, pp. 893-918.

[10] S. Hallermann, J. Larmer and J.R. Mergendoller, Project Based Learning Toolkit Series PBL In Elementarry Grades : A Step-byStep for Designing and Managing Standards Focused Project. Buck Institute for Education, 2011

[11] S. Hawanti, "Implementing Indonesia's English language teaching policy in primary schools: The role of teachers' knowledge and beliefs," International Journal of Pedagogies and Learning, Vol. 9, pp. 162-170, 2014

[12] P.A. Ertmer, A.T. Ottenbreit-Leftwich, O. Sadik, E. Sendurur, and P. Sendurur, "Teacher beliefs and technology integration practices: A critical relationship," International Journal Computers and Education, vol. 59, 2012,pp. 423-435.

[13] C. Tuğrul Mart, "Passionate Teacher: Teacher Commitment and Dedication to Student Learning," International Journal of Academic Research in Progressive Education and Development, vol. 2, 2013, pp. 2226-6348.

[14] J.A. Ros and P. Gray, "School Leadership and Student Achievement: The Mediating Effects of Teacher Beliefs," Canadian Journal Of Education, vol. 29, 2006, pp. 798-822.

[15] R.S. Abdullah, 2014. Pembelajaran Saintifik untuk Implementasi Kurikulum 2013. Jakarta: Bumi Aksara. 